Aleksandar Naumoski ${ }^{1 *}$, Peter Juhasz ${ }^{2}$

${ }^{1}$ Ss. Cyril and Methodius University in Skopje, Faculty of Economics, Skopje, Macedonia

${ }^{2}$ Corvinus University of Budapest, Corvinus Business School, Budapest, Hungary

\title{
The Impact of Inflation and Operating Cycle on the Corporate Cash Holdings in South-East Europe
}

DOI: 10.7595/management.fon.2018.0026

Abstract:

Research Question: This paper investigates the influence of the inflation and operating cycle on the corporate cash holdings. Motivation: In an early study, Keynes (1936) provides a theoretical foundation for determining the optimal cash level as a balance of costs and benefits of cash holdings. However, the optimal corporate cash amount is not only dependent on many company-specific factors (Opler et al., 1999), but it is also associated both with the corporate governance structure and the institutional and macroeconomic environment (Ozkan and Ozkan, 2004). Anand et al. (2018) confirmed the impact of a set of macroeconomic factors, but recent studies distinguished inflation as a critical factor of the changes of the company cash holdings (Curtis et al., 2017). Idea: The main idea of the paper is to examine whether inflation as a crucial macroeconomic factor and the operating cycle as a vital microeconomic factor have substantial influence on the corporate cash holdings, and which direction this impact may take. Data: We used company financial data from a sample of 868 publicly traded firms from ten South-East European countries between the years of 2006 and 2015 , obtained from the Thomson Reuters Datastream database.Tools: We apply a balanced panel regression model involving the yearly change of the cash ratio as a dependent variable, and the country $\mathrm{CPI}$, the operating cycle and other firmspecific control variables as explanatory variables. Findings: Results confirm that both the inflation and the operating cycle have a substantial influence on the change of the corporate cash holdings. The relationship of the change in cash and the inflation is non-linear and best described by a U-shaped curve. At the same time, there is a straight linear relationship between the change in cash holdings and the operating cycle. Moreover, we have found that the changes in the corporate cash holdings are positively related with the size of the company, the operating cash flow and the capital expenditures, but inversely related with the change of the networking capital and the change of short and long-term debt. Contribution: This paper reveals the effect of macro-control policies on corporate cash holdings, and, most importantly, it provides a reference for corporate managers to optimise the allocation of resources based on changes in the macro-financial environment and their own financial circumstances.

Keywords: CPI, liquidity, working capital, operating cycle, panel regression, corporate cash holdings

JEL classification: E31, G20, G32, G39

\section{Introduction}

What drives corporate cash holdings? In the classic Baumol-Tobin model (Meltzer, 1963), only the daily cash burn, the interest rate level and the transaction costs determine the optimum, while the Miller-Orr model (Miller \&Orr, 1966) adds minimum cash need and standard deviation of daily cash changes. While the importance of these parameters is widely accepted, when performing an outside analysis even today, most of these factors are extremely hard to estimate. Thus, empirical papers usually focus on metrics that are easier to track. 
Chief Financial Officers (CFOs) play a significant and dynamic role in the company's development and contribute to achieving all the company's objectives (Petkovic et al., 2018). Cash management is one of the primary responsibilities of the CFO. There are four motives for firms to hold cash: a transaction motive, precautionary motive, tax motive, and agency motive (Bates et al., 2009, p. 1988). Managers trying to maximise the shareholder's wealth should determine the optimal cash level, that is the cash level at which the marginal benefits of cash holding are equal to the marginal cost of cash holdings. The cost of holding cash is the opportunity cost since this asset earns low or zero return. The benefits of holding cash are more extensive. The most commonly stated are the following. i) cash is a safety reserve that can reduce the likelihood of financial distress and allows the firm to cover the unexpected loss; ii) it can be used to finance the firm's activities and investments when other sources are restricted or costly; and iii) holding cash avoids the cost of raising external funds and the need to liquidate other assets for providing funds. Keynes (1936) provides a theoretical foundation for determining the optimal holdings of liquid assets.

In the period of economic instability, the rising inflation hurts liquid corporate assets. As the prices of the raw materials and other inputs rise, the company spends more on financing its operating activities. Moreover, managers who anticipate further inflation build stocks of raw materials and other inputs to cope with the inflation risk reducing the cash holdings even further. When the nominal interest rates rise due to the higher inflation, managers are assumed to try to reallocate the cash holdings into interest-bearing assets that are cash substitutes and are also cash equivalents. Thus, inflation may have an adverse effect on the corporate cash holdings.

At the same time, current and anticipated inflation should have a positive effect on the liquid assets holdings as the loss in the purchasing power calls for more cash to cover payments due. Furthermore, in the period of higher inflation, the restrictive monetary policy may come to the scene making external financing constrained, calling for more cash to mitigate the risk of financial distress.

Thus, inflation may have both a negative and a positive effect on the corporate cash holdings. Wang et al. (2014) also state that as inflation starts to rise, corporate cash holdings decline to a certain level. After that point, as inflation further climbs, the corporate cash holdings begin to increase. That means that there is a $\mathrm{U}$-shaped non-linear relationship between the inflation and cash holding.

The operating cycle of the company starts with the purchase of raw materials, goes through the inventory conversion period, consecutive sales turnover days, and ends with the collection of receivables. The length of the operating cycle is influenced by the industry and several company-specific factors, such as the nature of the operating activities, its business models, and management efficiency. A longer operating cycle means more capital invested in current assets, which decreases the firm's cash supply and reduces cash holdings. Therefore, we can expect negative relations between the operating cycle and cash holding. Wang et al. (2014) state that the relationship might be U-shaped. When the operating cycle extends, the cash holdings decrease. With further lengthening of the operating cycle, primarily if it is caused by a slower receivables collection, the company must increase its cash holdings and other liquid assets to overcome the negative consequences of the increased liquidity risk.

This paper aims to investigate the influence of inflation and operating cycle on corporate cash holdings. Moreover, we are also interested in what direction this impact may take. Therefore, we state the hypotheses in the following form:

H1: Inflation has a statistically significant effect on the corporate cash holdings, but the relationship is nonlinear.

H2: Operating cycle has a statistically significant connection with the corporate cash holdings, but the relationship is non-linear.

The link between inflation and the operating cycle is indirect. The managers who anticipate a further increase in inflation spend more money now and make a purchase of the raw materials in advance, build the inventory in order to avoid the increased cost and make excess reserves. This behaviour extends the inventory period and automatically lengthens the operating cycle. We can see that these three variables (inflation, operating cycle and cash) are tightly related. Therefore, in this paper, we focus only on inflation as a curtail macroeconomic variable, and on the operating cycle as a curtail microeconomic variable to explain the corporate cash holdings. 
The paper is organised as follows: Part 2 offers a literature review, Part 3 explains the methodology, Part 4 presents the results, while in Part 5 the main conclusions are presented.

\section{Literature Review}

Researchers have discovered a wide variety of variables with a considerable influence on cash holdings. Company-specific factors with a significant effect on the cash level include, among others, a short-term debt to the total of assets ratio, short-term liabilities to assets, return on assets, firm size, working capital to assets ratio (Hall et al., 2014), market value to book value and R\&D/Sales (Wasiuzzaman, 2014), risk (cash flow volatility), and effective tax rate (Bigelli \& Sanchez-Vidal, 2012).

It seems that strategy also counts. Subramaniam et al. (2011) concluded that diversified companies hold significantly less cash than their focused counterparts, which they explained by the availability of the internal capital market. Hall et al. (2014) showed that in Central and Eastern Europe, companies in more marketoriented economies (based on EBRD transition indicators) held more cash than those in other countries. They also found that privately owned firms tend to carry more money than public ones. Based on a sample from the US, Gao et al. (2013) concluded that private firms held approximately half as much cash as public companies did.

It seems that these differences result partly from management knowledge and experience. D'Mello et al. (2008) investigated spin-offs to find that managers allocate higher cash ratios to smaller companies, and to firms with high research and development expense ratio, low net working capital ratio, and low leverage. Boileau and Moyen (2016) and Azar et al. (2016) argue that the opportunity cost of holding cash has declined; Nikolov and Whited (2014) have found that agency cost affects corporate cash holdings, such as the private benefits of managers form excess perquisite consumption, and the insufficient managerial shareholdings are the reason for the recent increase in the cash levels.

At the same time, we also know about some macro factors influencing the cash level. For example, Chen and Mahajan (2010) showed that firms tend to hold more cash when the economy expands (GDP grows), or the inflation and the credit spreads are on the rise. In contrast, budget deficit, corporate tax rate and leverage hurt corporate cash holdings. In addition to confirming these results, Anand et al. (2018) identify interest rates, the stock market index, local currency depreciation and sudden jumps in oil prices as having a positive effect on the amount of cash held by firms. In the case of the US, Graham and Leary (2018) have found that cross-sectional relations between cash holdings and firm characteristics are stable throughout the century, though characteristics explain little of the trends in aggregate cash. Macroeconomic conditions, corporate profitability and investment, and (since 2000) repatriation taxes explain aggregate cash over the last century.

Aside from examining the set of macroeconomic variables as determinants of cash holdings, some studies examine only the impact of inflation on cash holdings of the companies. Thus, according to Curtis et al. (2017), inflation is a key factor in the changes of the company cash holdings, which are imperfectly hedged against inflation, and hence, changes in inflation alter the real value of a firm's liquid asset portfolio causing it to readjust these balances. In the case of Brazilian companies, Natke (2010) finds that interest rates have a strong and elastic impact on liquid asset demand when explicitly controlled for inflation and firms appear to conserve on liquid asset holdings as the rate of inflation increases, suggesting a more careful management of payments flows. Wang et al. (2014) found a strong non-linear relationship between the inflation and cash holdings, and between the operating cycle and the cast holdings.

Table 1 provides a review of variables that are relevant to the cash holding decisions of firms based on our literature review. While most of the earlier papers focused on developed countries (US, UK) and Asia (India, China), our knowledge is still limited concerning the emerging countries in Europe. This paper uses data from ten Southern European countries to learn whether some of the factors listed in the literature play a role in determining the corporate cash holdings in a region characterised by unique national development paths, limitedly developed capital markets, and particularly hit by the recent financial crisis. After reviewing the literature for the main factors and their theoretical effects, the paper presents the dataset and lists our most important findings. 
Table 1: Summary of the variables and their effect on corporate cash holdings

\begin{tabular}{|c|c|c|}
\hline Variable & $\begin{array}{l}\text { Effect on } \\
\text { cash holding }\end{array}$ & References \\
\hline Inflation & $\begin{array}{l}\text { Positive and } \\
\text { Negative }\end{array}$ & $\begin{array}{l}\text { Curtis et al. (2017); Fallah and Hashemi (2017);Jazz et al. } \\
\text { (2016);Wang et al. (2014);Natke (2001) }\end{array}$ \\
\hline Operating cycle & Negative & $\begin{array}{l}\text { Fallah and Hashemi (2017);Jazz et al. (2016);Wang et al. } \\
\text { (2014) }\end{array}$ \\
\hline Firm size & $\begin{array}{l}\text { Positive and } \\
\text { Negative }\end{array}$ & $\begin{array}{l}\text { Miller and Orr (1966);Mulligan (1997); Peterson and Rajan } \\
\text { (2003); Barclay and Smith (1995); Brennan and Hughes } \\
\text { (1991); Collins et al. (1981);Whited (1992); Fazzari and } \\
\text { Petersen (1993); Kim et al. (1998); Bates et al. (2009); Titman } \\
\text { and Wessels (1988); Ozkan (1996); Opler et al. (1999); } \\
\text { Ferreira and Vilela (2004); Nguyen (2018) }\end{array}$ \\
\hline $\begin{array}{l}\text { Liquid asset substitutes } \\
\text { (net working capital less of cash) }\end{array}$ & Negative & Lang et al. (1994) \\
\hline Leverage & $\begin{array}{l}\text { Positive and } \\
\text { Negative }\end{array}$ & $\begin{array}{l}\text { John (1993); Baskin (1987); Bates et al. (2009); Acharya et al. } \\
\text { (2007); Opler et al. (1999); Ferreira and Vilela (2004) }\end{array}$ \\
\hline Cash flow & $\begin{array}{l}\text { Positive and } \\
\text { Negative }\end{array}$ & $\begin{array}{l}\text { Kim et al. (1998); Ferreira and Vilela (2004); Bates et al. } \\
\text { (2009);Nguyen (2018) }\end{array}$ \\
\hline Current liabilities & $\begin{array}{l}\text { Positive and } \\
\text { Negative }\end{array}$ & Kim et al. (1998); Ferreira and Vilela (2004); Bates et al. (2009) \\
\hline Capital expenditures & $\begin{array}{l}\text { Positive and } \\
\text { Negative }\end{array}$ & Riddick and Whited (2009); Bates et al. (2009);Nguyen (2018) \\
\hline
\end{tabular}

Source: Authors' theoretical research results

\section{Description of the Dataset}

To investigate the link between the listed factors and the change of corporate cash holdings we used a sample of publicly traded firms from the South-East European region (the SEE countries), from 2006 to 2015, obtained from the Thomson Reuters Eikon and Datastream database. The data on CPI were obtained from the International Monetary Fund - International Financial Statistics. Ten countries from the SEE region are included: Bosnia and Herzegovina, Bulgaria, Montenegro, Croatia, Greece, Romania, Macedonia, Slovenia, Serbia, and Turkey. These data include both survivors and non-survivors that appeared on the Eikon and Datastream database at any time in the sample period. When designing the sample, we excluded: i) firms in the financial sector (because of their radically different business model, considerable holdings of marketable securities, and their statutory capital requirements); ii) utilities (their cash holdings and operation can be subject to regulatory supervision); iii) firms with negative sales and/or assets; iv) firms with operating cycles below zero; $v$ ) firms with missing observation for any variable. Finally, our sample encompasses 868 companies and 8680 firm-year observations.

The cash measure in this paper is defined broadly as cash and short-term investments, taken as a consolidated measure of cash holdings. Following Wang et al. (2014), the primary dependent variable used in the analysis below is the change in the cash ratio measured as the difference in cash and short-term investments between year $t$ and $t-1$, divided by the total assets of year $t$.

Explanatory variables of corporate cash holdings are listed following the explanations of the transaction and precautionary motive of holding cash. The variables used are as follows:

(1) Inflation. We use the accumulated Consumer Price Index $(2005=100)$ for each country taken from IMF International Financial Statistics. When interpreting the connection with a change in cash, we have to see that, as yearly inflation rates are mostly positive, some of the changes due to time passing might be allocated to this variable.

(2) Cycle. The operating cycle is measured as a sum of the inventory conversion period and the account receivables collection period. We divide this sum by 1000 for statistical calculations, but the interpretation is made in day terms.

(3) Account receivables period. We measure the period for collecting of receivables as (Accounts Receivable / Sales) x 365.

(4) Account payables period. The ratio is calculated as (Accounts payable/Cost of goods sold) $\times 365$.

(5) Inventory conversion period. It is obtained as (Inventory / Cost of goods sold) x 365.

(6) $\Delta$ Net working capital ratio. We measure this ratio as the difference of NWC minus cash and shortterm investments, between year $t$ and year $t-1$, divided by the total assets of year $t$.

(7) $\Delta$ Leverage. This quantity is the difference of total (long-term plus short-term) debt between year $t$ and year $t-1$ divided by total assets of year $t$. 
(8) $\Delta$ Current liabilities. The variable quantifies the difference of current liabilities between year $t$ and year $t-1$ divided by total assets of year $t$.

(9) Firm size. We measure this variable as the natural logarithm of total assets in the year 2015 using the consumer price index of the respective country.

(10) Cash flow ratio. This measure is defined as earnings before tax plus depreciation over the total assets in line with Ozkan and Ozkan (2004). Opler et al. (1999) and Bates et al. (2009) assess cash flow as earnings after interest, dividends and taxes plus depreciation, but due to insufficient data in our sample, we had to stick to the less sophisticated solution.

(11) Capital expenditures ratio. The ratio is measured as capital expenditures over the total of assets.

\section{Empirical Findings}

Recent studies show large amounts of cash held by companies in developed countries, especially in the US, and this large increase in corporate cash balances in recent years has garnered much attention in the academic studies. Thus, according to Graham and Leary (2018) cash represents $15.69 \%$ of the total assets in the US, and in the UK companies it amounts to 9.9\% (Ozkan\&Ozkan, 2004, p.2117). The average cash to assets ratio for the SEE companies in the period $2006-2015$ was $6.9 \%$ where a big difference among the countries presented in Table 2 (lowest in B\&H, 4.2\% and highest in Turkey, 9.5\%). The cash holdings by the SEE emerging markets is much lower than those in the developed ones.

To understand the corporate policy in emerging markets we must first point out that emerging markets differ significantly from developed markets. Emerging markets are less developed, the companies have a lower quality of governance, they are facing illiquidity problems, the banking sector dominates in the structure of financial intermediation, unlike the US where financial markets have dominance in the financial architecture, and the emerging markets reveal big differences in the national characteristics and other macroeconomic factors (Naumoski \&Nestiorovski, 2018, pp. 481). The corporate environment has an impact on cash policy.

The change in the cash holdings to the total assets ratio ( $\triangle$ Cash) for the SEE countries for the years 20062015 averaged to $0.34 \%$ as presented in Table 2 . Some small differences appear among the ten countries in the sample, where the lowest yearly cash change shows in the case of Bosnia and Herzegovina, with an average decrease of $-0.03 \%$, while the highest change came from Turkey where the average increase was $0.79 \%$.

Table 2: Change in the cash holdings to total assets ratio, CPI, and the length of the operating cycle in the SEE countries (averages)

\begin{tabular}{|l|c|c|c|c|c|c|}
\hline \multicolumn{1}{|c|}{ Country } & $\begin{array}{c}\text { Cash to asset } \\
\text { ratio }\end{array}$ & $\boldsymbol{\Delta}$ Cash & CPI* & $\begin{array}{c}\text { Inflation } \\
\text { rate }\end{array}$ & $\begin{array}{c}\text { Operating } \\
\text { cycle (days) }\end{array}$ & $\mathbf{N}$ \\
\hline Bosnia and Herzegovina & 0,042 & -0.0003 & 116.3 & $2.07 \%$ & 397 & 52 \\
Bulgaria & 0,052 & 0.0014 & 132.6 & $3.97 \%$ & 741 & 139 \\
Croatia & 0,072 & 0.0012 & 115.7 & $2.28 \%$ & 196 & 73 \\
Greece & 0,071 & 0.0036 & 113.9 & $1.70 \%$ & 303 & 187 \\
Macedonia & 0,052 & -0.0001 & 115.9 & $2.40 \%$ & 515 & 32 \\
Montenegro & 0,043 & 0.0003 & 120.8 & $3.08 \%$ & 462 & 14 \\
Romania & 0,079 & 0.0029 & 132.2 & $4.45 \%$ & 489 & 93 \\
Serbia & 0,053 & 0.0035 & 156.1 & $7.44 \%$ & 820 & 58 \\
Slovenia & 0,051 & 0.0015 & 114.0 & $2.03 \%$ & 108 & 27 \\
Turkey & 0,095 & 0.0079 & 155.2 & $8.30 \%$ & 193 & 193 \\
\hline SEE & $\mathbf{0 , 0 6 9}$ & $\mathbf{0 . 0 0 3 4}$ & $\mathbf{1 3 4 . 5}$ & $\mathbf{3 . 7 7 \%}$ & $\mathbf{4 1 0}$ & $\mathbf{8 6 8}$ \\
\hline
\end{tabular}

*2005=100 Source: Authors' calculations

\subsection{Results of the descriptive statistics}

In the period of the global financial crisis of 2007-2009 and afterwards, until 2010, the corporate cash holdings decreased (Figure 1 and 2), then from 2011 onwards, the cash holdings started to increase. Figure 1 depicts the relationship of the $\Delta$ Cash with the CPI. The average CPI in SEE countries was continuously rising, and the average inflation rate was $3.77 \%$ in the SEE region on a year-by-year basis. The CPI curve shows a constant upward trend with the highest increase in 2008 when the inflation rate is high in all countries, and in SEE on average amounts to $8.58 \%$. Afterwards, the rate of inflation continuously and slowly reaches $1.96 \%$ in 2015 . 


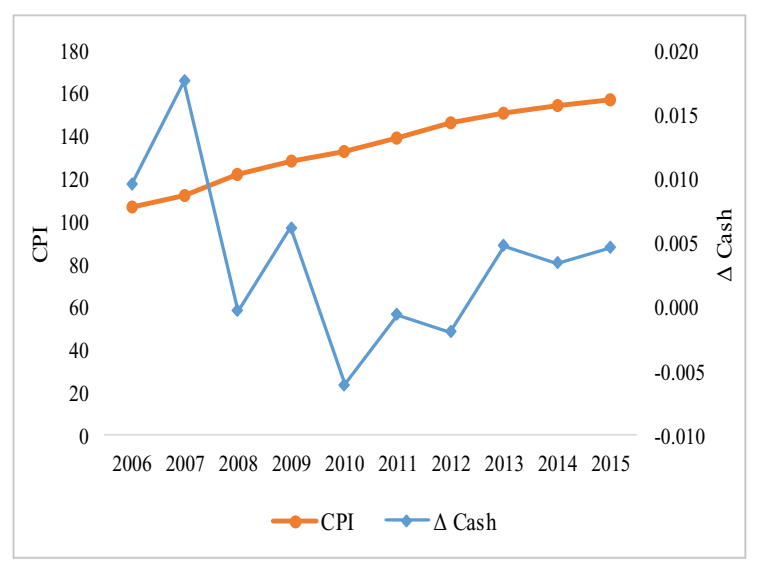

Figure 1: Average $\Delta$ Cash and accumulated CPI

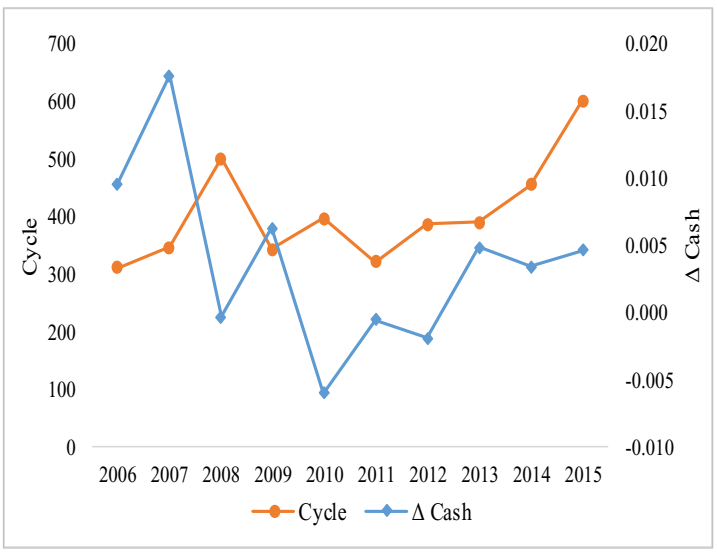

Figure 2: Average $\Delta$ Cash and Cycle

Figure 1 shows that when the inflation started to increase, the corporate cash holdings began to decrease. Here, the CPI was continually rising at a different rate, and the cash was dropping until 2010, then from the year 2011, it started to increase. This result suggests that there is no linear relationship between the cash and inflation, and the relationship can be explained by the U-shaped curve.

The operating cycle followed a similar trend to that of the change in cash (Figure 2). It decreased in the period of the great financial crisis and rose in the period of the economic recovery. Therefore, we can expect some positive association between the changes in cash and the length of the operating cycle.

Table 3 presents the descriptive statistics of the exogenous variables. Based on Table 2, we can notice that the average operating cycle in SEE countries was 410 days, which comes from the average inventory conversion period of 231.2 days and average account receivables collection period of 178.7 days. The average account payables period is 306 days and is much higher than the receivables period. Also, we can notice that Serbia and Turkey are countries with the highest, while Greece shows the lowest, average CPI and inflation. The highest average cycle measured was that of Serbia amounting to 820 days (which is due to the extensive inventory period of 413.6 days, and also extensive account receivables period of 406.4 days). The lowest quantity, 108 days, was obtained for Slovenia (which is due to the reasonably short inventory period of 52.7 days, and also quite short account receivables period of 55.3 days). Table 3 also presents the summary statistics for the rest of the exogenous variables.

Table 3: Descriptive statistics of the variables

\begin{tabular}{lccccc}
\hline \multicolumn{1}{c}{ Variable } & Mean & Median & Maximum & Minimum & Std. Dev. \\
\hline$\Delta$ Cash & 0.0034 & 0.0002 & 0.5288 & -1.1895 & 0.0600 \\
$\mathrm{CPI}$ & 134.5 & 123.4 & 221.8 & 102.5 & 27.9 \\
$\mathrm{CPI}^{2}$ & 18867.1 & 15222.7 & 49199.3 & 10498.6 & 8670.0 \\
Cycle & 0.4099 & 0.1792 & 70.1264 & 0.0005 & 1.9685 \\
Cycle $^{2}$ & 4.043 & 0.032 & 4917.705 & 0.000 & 96.115 \\
Account receivables period $_{\text {Account payables period }}$ & 0.1787 & 0.0700 & 65.1525 & 0.0000 & 1.4560 \\
Inventory conversion period & 0.3066 & 0.0855 & 247.7127 & -0.1130 & 3.4772 \\
Cash flow ratio & 0.2312 & 0.0863 & 65.7340 & -0.0120 & 1.2054 \\
$\Delta$ Net working capital & 0.0377 & 0.0426 & 6.8469 & -6.3701 & 0.1767 \\
$\Delta$ Current liabilities & 0.0019 & 0.0019 & 8.5732 & -5.3734 & 0.2200 \\
$\Delta$ Leverage & 0.0068 & 0.0101 & 2.8713 & -8.7686 & 0.2463 \\
Capital expenditures & 0.0061 & 0.0000 & 1.7106 & -11.1334 & 0.2145 \\
Size & 0.0431 & 0.0214 & 1.7563 & 0.0000 & 0.0745 \\
\hline
\end{tabular}

Source: Authors' calculations 


\subsection{Regression analysis}

The determinants of the change in corporate cash holdings are investigated using a regression of $\Delta$ Cash ratio defined above on the set of exogenous variables defined and described above. The analysis was done on a balanced panel of data. To test our hypothesis, we estimate the following equation:

$$
\begin{array}{r}
\Delta \text { Cash }=\beta_{0}+\beta_{1} C_{P I}+\beta_{2} \operatorname{CPI}_{i, t}^{2}+\beta_{3} \text { Cycle }_{i, t}+\beta_{4} \text { Cycle }_{i, t}^{2}+\beta_{5} C_{i, t}+\beta_{6} \text { Size }_{i, t}+\beta_{7} \text { CAPEX }_{i, t}+ \\
B_{8} \Delta N W C_{i, t}+\beta_{9} \Delta \text { Currliab }_{i, t}+\beta_{10} \Delta \text { Lever }_{i, t}+\varepsilon_{i, t}(1)
\end{array}
$$

The analysis was performed using E-views. At the very least, using the Hausman test, we examined which regression model was the most appropriate. The results showed that the fixed effects model is best for the given data sample. According to Deloof (2003), fixed effects estimation assumes firm-specific intercepts, which capture the effects of those variables that are particular to each firm and that are constant over time. A disadvantage of fixed impact estimation is that it eliminates from the model any other factor that is timeinvariant.

We have run three regression models. In the first one, we excluded the operational cycle to focus only on the influence of inflation on the change in cash holdings. In the second regression, we omitted the CPI to consider just the effect of the operating cycle. In the third case, we ran the regression analysis with all variables included. Table 4 shows the results of the three regressions.

\begin{tabular}{|c|c|c|c|}
\hline \multirow{2}{*}{ Independent variables } & \multicolumn{3}{|c|}{ Dependent variable: $\Delta$ Cash } \\
\hline & $(1)$ & $(2)$ & (3) \\
\hline Intercept & 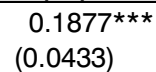 & $\begin{array}{l}0.0920^{\star \star \star \star} \\
(0.0364)\end{array}$ & $\begin{array}{l}0.1885^{\star \star \star} \\
(0.0433)\end{array}$ \\
\hline $\mathrm{CPI}$ & $\begin{array}{l}-0.0012^{\star * \star} \\
(0.0002)\end{array}$ & & $\begin{array}{l}-0.0012^{\star * *} \\
(0.0002)\end{array}$ \\
\hline $\mathrm{CPI}^{2}$ & $\begin{array}{l}0.0000^{* * *} \\
(0.0000)\end{array}$ & & $\begin{array}{l}0.0000^{* * *} \\
(0.0000)\end{array}$ \\
\hline Cycle & & $\begin{array}{l}-0.0022^{\star *} \\
(0.0009)\end{array}$ & $\begin{array}{l}-0.0020^{\star *} \\
(0.0009)\end{array}$ \\
\hline Cycle $^{2}$ & & $\begin{array}{c}0.0000 \\
(0.0000)\end{array}$ & $\begin{array}{c}0.0000 \\
(0.0000)\end{array}$ \\
\hline Cash flow & $\begin{array}{l}-0.0162^{\star * *} \\
(0.0045)\end{array}$ & $\begin{array}{l}-0.0157^{* * *} \\
(0.0045)\end{array}$ & $\begin{array}{l}-0.0163^{\star \star \star} \\
(0.0045)\end{array}$ \\
\hline Size & $\begin{array}{l}-0.0048^{\star \star} \\
(0.0022)\end{array}$ & $\begin{array}{l}-0.0045^{\star \star} \\
(0.0019)\end{array}$ & $\begin{array}{l}-0.0050^{\star \star} \\
(0.0022)\end{array}$ \\
\hline Capital expenditures & $\begin{array}{l}-0.0878^{\star \star \star} \\
(0.0114)\end{array}$ & $\begin{array}{l}-0.0778^{\star \star \star} \\
(0.0113)\end{array}$ & $\begin{array}{l}-0.0862^{* * \star} \\
(0.0114)\end{array}$ \\
\hline$\Delta$ Net working capital & $\begin{array}{l}0.1176^{\star \star \star} \\
(0.0049)\end{array}$ & $\begin{array}{l}0.1190^{* * \star} \\
(0.0048)\end{array}$ & $\begin{array}{l}0.1175^{\star \star \star} \\
(0.0049)\end{array}$ \\
\hline$\Delta$ Current liabilities & $\begin{array}{l}0.0693^{\star \star \star *} \\
(0.0045)\end{array}$ & $\begin{array}{l}0.0703^{* * *} \\
(0.0045)\end{array}$ & $\begin{array}{l}0.0692^{\star \star \star} \\
(0.0045)\end{array}$ \\
\hline$\Delta$ Leverage & $\begin{array}{l}0.0499 * * \star \\
(0.0039)\end{array}$ & $\begin{array}{l}0.0506^{* * *} \\
(0.0039)\end{array}$ & $\begin{array}{l}0.0500^{\star \star \star} \\
(0.0039)\end{array}$ \\
\hline $\begin{array}{l}\mathrm{R}^{2} \\
\text { Adjusted } \mathrm{R}^{2} \\
\text { F-statistic } \\
\text { Prob(F-statistic) }\end{array}$ & $\begin{array}{l}0.1483 \\
0.0528 \\
1.5533 \\
0.0000 \\
\end{array}$ & $\begin{array}{l}0.1475 \\
0.0519 \\
1.5427 \\
0.0000 \\
\end{array}$ & $\begin{array}{l}0.1503 \\
0.0548 \\
1.5732 \\
0.0000 \\
\end{array}$ \\
\hline
\end{tabular}

Table 4: Regressions on the change in cash ratio including inflation and firm characteristics

Note: Standard errors in parentheses. * significant at 10\%, ** significant at $5 \%,{ }^{* * *}$ significant at $1 \%$. Source: Authors' calculations 
The results from the regressions confirm that the $\mathrm{CPI}$ and the operating cycle have a strong influence on the change of corporate cash holdings. Also, the signs of the coefficient are according to our expectations. More precisely, we found that inflation has an adverse effect on the change of the cash holdings. However, since the squared CPI is also statistically significant and positive, it seems that the relationship is not linear, but there is a U-shaped curve that can explain the link, which is the effect of inflation on corporate cash holdings. This relationship confirms our hypothesis $\mathrm{H} 1$ : Inflation determines the corporate cash holdings, but there is a non-linear relationship. More precisely, empirical results confirm that when the inflation is rising the corporate cash holdings decrease to a certain level. After that point, the cash holdings are increasing together with the rising inflation.

In the second regression, we excluded CPI to quantify only the effect of the operating cycle. The results from the third regression are similar. Here we can see that the coefficient of the cycle is statistically significant, and the squared cycle is not significant. That indicates that the relationship among the operating cycle and the change in cash is linear and negative. This finding contradicts our hypothesis H2. Wang et al. (2014) show a similar concave function on Chinese data.

The other results from the analysis show that the change in the corporate cash holdings is positively related to the size, the cash flow and the capital expenditures. It is negatively related to the change of the net workingcapital and to the short- and long-term debt ratios.

The negative relationship with the operating cash flow means that the operating cash flow is a ready source of liquidity that SEE companies can have used for the financing of their operating activities, so it is considered a substitute of cash. The negative relationship with the company size can be explained by the economics of scale in cash management, the need for reducing the fixed cost of raising external capital. Consequently, huge firms have a relatively modest rise in cash, while the smaller companies experience more extensive growth than the bigger ones. The negative relations between the cash change and CAPEX can be explained by the fact that company investments lead to lower savings and less cash, while higher capital expenditure leads to a decrease in the cash holdings.

The regression results indicate that cash holdings increased together with the net working capital. This result contradicts our expectations, but it is in line with what was found by Guney et al. (2007) and Wang et al. (2014). Company borrowings also had a positive effect on the changes in cash holding, just as Guney et al. (2007) explained. To the extent to which the leverage of firms can act as a proxy for their ability to issue debt, one would expect a negative (substitution effect) association between leverage and cash holdings. However, as leverage increases firms are likely to accumulate more substantial cash reserves to minimise the risk of financial distress and costly bankruptcy. Thus, one would expect a positive (precautionary effect) relationship between cash holdings and leverage at high levels of indebtedness.

\subsection{Inflation effect on changes in cash holdings in the SEE countries}

The relationship between the $\mathrm{CPI}$ and corporate cash holdings at first glance is depicted in Figure 1. The inflation rate in all SEE countries was higher before the global financial crisis reaching the highest level in 2008. The cash holdings of the companies in this period were reduced due to the higher cost of operation and the dynamic opportunities. Afterwards, in expectation of inflationary conditions, where interest rates went up, firms probably invested in long- and short-term deposits, so they held more marketable securities. Thus the cash holdings are increasing.

The results of the regression analysis have proven the existence of a non-linear relationship between inflation and cash holdings. Both the $\mathrm{CPI}$ and the $\mathrm{CPI}^{2}$ are statistically significant, but with different signs. Since the $\mathrm{CPI}$ is negative and the $\mathrm{CPI}^{2}$ is positive, which implies that in expectation of inflationary conditions, interest rates go up and firms hold more cash equivalents. The increase in inflation leads to a reduction in cash holdings to a minimum point, and then this effect will turn from negative to positive. We reran the regression with the $\mathrm{CPI}$ and the $\mathrm{CPI}^{2}$ as only independent variables and came to this expression of the relationship between cash and inflation: $\Delta$ Cash $=0.127607-0.001618 \mathrm{CPI}+0.00000495 \mathrm{CPI}^{2}$. The relationship is a quadratic function that can be depicted in Figure 3 with a U-shaped curve with the lowest point of cash decrease of $-0.46 \%$, when the CPI is 163 points. 


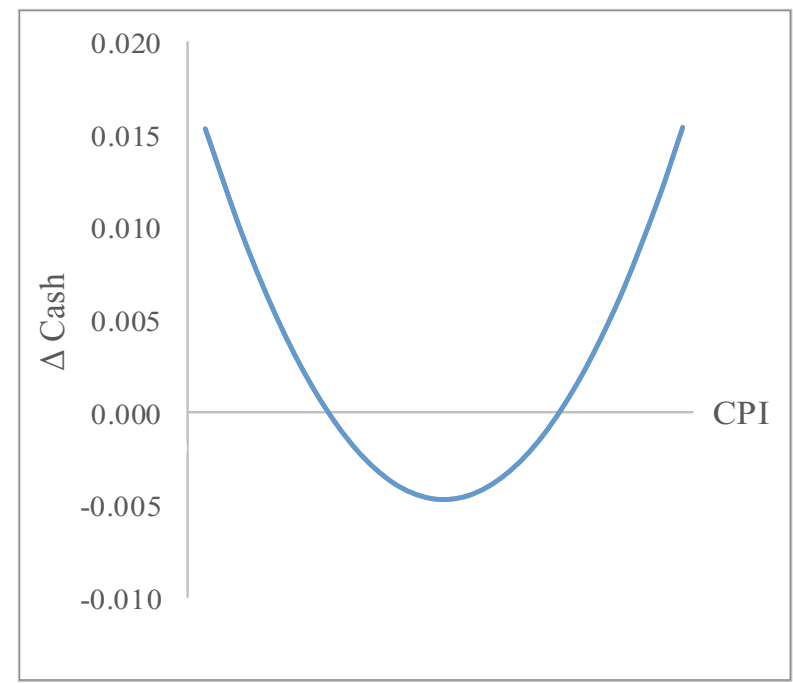

Figure 3: Accumulated CPI and changes in cash holdings in SEE countries

\section{Conclusion}

The optimal cash level of the company is determined by a range of macroeconomic and microeconomic company specific factors. In this paper, we investigate the effect of inflation as a proxy for the macro- and operating cycle as a comprehensive measure of the corporate specific factors on the cash holdings in the companies of the SEE region. More specifically, we examine how the companies adjusted their cash level under changing micro and macro factors.

We analysed 868 companies from ten South-East European countries (Bosnia and Herzegovina, Bulgaria, Montenegro, Croatia, Greece, Romania, Macedonia, Slovenia, Serbia and Turkey) for the period 2006-2015. We found that the corporate cash holdings increased slowly by $0.34 \%$ annually on average in the given period. The $\mathrm{CPI}$ and the operating cycle have a strong influence on the adjustment of cash holdings. The inflation (CPI measured as 2005=100) had a non-linear relationship with the change of corporate cash holdings, which could be expressed with a quadratic function and depicted with a U-shaped curve. Thus, with the rise of inflation, corporate cash holdings decreased, probably because of rising prices of the inputs and spending on additional stocks to overcome future inflation risk. However, at a specific point, the corporate cash started to grow with the increase in inflation. That might be because corporate managers tried to shift toward interest-bearing cash equivalents to mitigate the loss of purchasing power and the rise of nominal interest rate. They might also build up a cash reserve to avoid the financial distress that could arise in the unfavourable economic environment.

We identified a negative linear relationship between the change in cash holdings and the length of the operating cycle. That means that a lengthening operating cycle (either due to an extended production period or more likely in an unfavourable economic environment due to the lengthening of the collection period) implies a cash holding decrease.

Other firm-specific variables also had a strong influence on the adjustment of corporate cash holdings. We found that the change in the corporate cash holdings was positively related to the size of the company, the operating cash flow and the capital expenditures. At the same time, it was negatively related with both the change of the net working capital and the change of short and long-term debt ratio.

\section{Acknowledgements}

Some parts of the paper have been presented at the 2nd International Scientific Conference on economics and management - EMAN 2018, Ljubljana, Slovenia (www.eman-conference.org) 


\section{REFERENCES}

[1] Acharya, V. A., Almeida, H., \&Campello, M. (2007). Is cash negative debt? A hedging perspective on corporate financial policies. Journal of Financial Intermediation, 16, 515-554. DOI: 10.1016/j.jfi.2007.04.001

[2] Anand, L., Thenmozhi, M., Varaiya, N., \&Bhadhuri, S. (2018). Impact of macroeconomic factors on cash holdings?: A dynamic panel model. Journal of Emerging Market Finance, 17(1_suppl), S27-S53. DOI:10.1177/0972652717751536

[3] Azar, J., Kagy, J., \& Schmalz, M. (2016). Can changes in the cost of carry explain the dynamics of corporate "cash" holdings? Review of Financial Studies, 29, 2194-2240. https://doi.org/10.1093/rfs/hhw021.

[4] Barclay, M.J., \& Smith Jr., C.W. (1995). The maturity structure of corporate debt. Journal of Finance, 50, 609-631. DOI: 10.1111/j.1540-6261.1995.tb04797.x

[5] Baskin, J. (1987). Corporate liquidity in games of monopoly power. Review of Economics and Statistics, 69, 312-319. DOI: 10.2307/1927239

[6] Bates, W.T., Kahle, M.K., \& Stulz, M.R. (2009). Why do U.S. firms hold so much more cash than they used to? The Journal of Finance, 64(5), 1985-2021. DOI: 10.2307/1927239

[7] Bigelli, M., Sanchez-Vidal, J. (2012). Cash holdings in private firms. Journal of Banking and Finance, 36, 26-35. DOI:10.1016/j.jbankfin.2011.06.004

[8] Boileau, M., \&Moyen, N. (2016). Corporate cash holdings and credit line usage. International Economic Review, 57, 1481-1506.

[9] Brennan, M., \& Hughes, P. (1991). Stock prices and the supply of information. Journal of Finance, 46, 1665-1691. DOI: 10.1111/j.1540-6261.1991.tb04639.x

[10] Chen, N., \& Mahajan, A. (2010). Effects of macroeconomic conditions on corporate liquidityinternational evidence. International Research Journal of Finance and Economics, 35, 112-129.

[11] Collins, D., Rozeff, M., \& Dhaliwal, D. (1981). The economic determinants of the market reaction to proposed mandatory accounting changes in the oil and gas industry. Journal of Accounting and Economics, 3, 37-71. DOI: 10.1016/0165-4101(81)90034-3

[12] Curtis, C. C., Garin, J., \&Mehkari, S. M. (2017). Inflation and the evolution of firm-level liquid assets. Journal of Banking \& Finance, 81, 24-35. DOI:10.1016/j.jbankfin.2017.04.008

[13] D’Mello, R., Krishnaswami, S., \& Larkin, P. J. (2008). Determinants of corporate cash holdings: Evidence from spin-offs. Journal of Banking and Finance, 32, 1209-1220. DOI:10.1016/j.jbankfin.2007.10.005

[14] Deloof, M. (2003). Does working capital management affect profitability of Belgian firms? Journal of Business Finance \& Accounting, 30(3\&4), 573-587. DOI: 10.1111/1468-5957.00008

[15] Fallah, S., \& Hashemi, S.A. (2017). The effects of inflation and operating cycle on cash holdings (liquidity) of listed companies in Tehran stock exchange. Asian Economic and Financial Review, 7(1), 43-51. DOI: 10.18488/journal.aefr/2017.7.1/102.1.43.51

[16] Fazzari, S.M., \& Petersen, B. (1993). Working capital and fixed investment: New evidence on financing constraints. Rand Journal of Economics,24, 328-342. DOI: 10.2307/2555961

[17] Ferreira, M. A., \&Vilela, A. S. (2004). Why do firms hold cash? Evidence from emu countries. European Financial Management, 10(2), 295-319. DOI: 10.1111/j.1354-7798.2004.00251.x

[18] Gao, H., Harford, J., \& Li, K. (2013). Determinants of corporate cash policy: Insights from private firms. Journal of Financial Economics, 109, 623-639. DOI: 10.1016/j.jfineco.2013.04.008

[19] Graham, J.R., \& Leary, M.T, (2018). The Evolution of Corporate Cash. The Review of Financial Studies, hhy075, https://doi.org/10.1093/rfs/hhy075

[20] Guney, Y., Ozkan, A., \&Ozkan, N. (2007) International evidence on the non-linear impact of leverage on corporate cash holdings. Journal of Multinational Financial Management, 17, 45-60. DOI: 10.1016/j.mulfin.2006.03.003

[21] Hall, T., Mateus, C., \&Mateus, I. B. (2014). What determines cash holdings at privately held and publicly traded firms? Evidence from 20 emerging markets. International Review of Financial Analysis, 33, 104-116. DOI:10.1016/j.irfa.2013.11.002

[22] Jazz, H. R., Hajalizadeh, M., Tombeki, E. B., \& Lori, B. G. (2016). The impact of inflation rate and operating cycle on cash holdings of firms. Academic Journal of Accounting and Economic Researches, 5(3), 86-94.

[23] John, T.A. (1993). Accounting measures of corporate liquidity, leverage, and costs of financial distress. Financial Management, 22, 91-100. DOI: 10.2307/3665930

[24] Keynes, J.M. (1936). The General Theory of Employment. In: Interest and Money. Harcourt Brace, London.

[25] Kim, C.S., Mauer, D.C., \& Sherman, A.E. (1998). The determinants of corporate liquidity: theory and evidence. Journal of Financial and Quantitative Analysis, 33, 305-334. DOI: 10.2307/2331099 
[26] Lang, L., Poulsen, A., \& Stulz, R. (1994). Asset sales, firm performance, and the agency costs of managerial discretion. Journal of Financial Economics, 37, 3-37. DOI: 10.1016/0304-405X(94)00791-X

[27] Meltzer, A. H. (1963). The demand for money: a cross-section study of business firms. The Quarterly Journal of Economics, 77, 405-424. DOI: 10.2307/1879569

[28] Miller, M.H., \& Orr. D. (1966). A model of the demand for money by firms. Quarterly Journal of Economics, 8(3), 413-435. DOI: 10.2307/1880728

[29] Mulligan, C.B. (1997). Scale economies, the value of time, and the demand for money: longitudinal evidence from firms. Journal of Political Economy, 105(5), 1061-1079. DOI: 10.1086/262105

[30] Natke, P.A (2001). The firm demand for liquid assets in an inflationary environment. Applied Economics, 33(4), 427-436. DOI: 10.1080/00036840122635

[31] Naumoski, A., \&Nestorovski, M. (2018). Ex-ante equity risk premia:expectational estimates using stock market returns forecasts in the emerging equity market. Panoeconomicus, 65(4), 479-507. DOI: 10.2298/PAN130925004N

[32] Nguyen, C. (2018). The asymmetry in firms' mechanisms of cash holdings adjustments: evidence from the G-5 economies. Review of Quantitative Finance and Accounting. DOI: 10.1007/s11156-0180754-1

[33] Nikolov, B., \& Whited, T. (2014). Agency conflicts and cash: Estimates from a dynamic model. Journal of Finance 69, 1883-921.https://doi.org/10.1111/jofi.12183. .

[34] Opler, T., Pinkowitz, L., Stulz, R.M., \& Williamson, R. (1999). The determinants and implications of corporate cash holdings. Journal of Financial Economics, 52 (1), 3-46. DOI: 10.1016/S0304405X(99)00003-3

[35] Ozkan, A. (1996). Corporate bankruptcies, liquidation costs and the role of banks. The Manchester School, 64(S1), 104-119. DOI: 10.1111/j.1467-9957.1996.tb01457.x

[36] Ozkan, A., \&Ozkan, N.(2004). Corporate cash holdings: An empirical investigation of UK companies. Journal of Banking \& Finance, 28(9), 2103-2134. DOI: 10.1016/j.jbankfin.2003.08.003

[37] Peterson, M., \&Rajan, R. (2002). Does distance still matter? The information revolution in small business lending. Journal of Finance, 57(6), 2533-2570. DOI: 10.1111/1540-6261.00505

[38] Petkovic, G., Konjikusic, S., Barjaktarovic, L., \&Pindzo, R. (2018). What is the real state of financial management in companies in the Republic of Serbia? Management:Journal of Sustainable Business and Management Solutions in Emerging Economies.DOI: 10.7595/management.fon.2018.0002

[39] Riddick, L. A., \& Whited, T.M. (2009). The corporate propensity to save. Journal of Finance, 64(4), 1729-1766. DOI: 10.1111/j.1540-6261.2009.01478.x

[40] Subramaniam, V., Tang, T. T., Yue, H., \& Zhou, X. (2011). Firm structure and corporate cash holdings. Journal of Corporate Finance, 17, 759-773. DOI:10.1016/j.jcorpfin.2010.06.002

[41] Titman, S., \& Wessels, R. (1988). The determinants of capital structure choice. Journal of Finance, 43(1), 1-19. DOI: 10.1111/j.1540-6261.1988.tb02585.x

[42] Wang, Y., Ji, Y., Chen, X., \&Song, C. (2014). Inflation, operating cycle, and cash holdings.China Journal of Accounting Research,7, 263-276. DOI: 10.1016/j.cjar.2013.07.001

[43] Wasiuzzaman, S. (2014). Analysis of corporate cash holdings of firms in Malaysia. Journal of Asia Business Studies, 8(2), 118-135. DOI:10.1108/JABS-10-2012-0048

[44] Whited, T. (1992). Debt, liquidity constraints, and corporate investment: Evidence from panel data. Journal of Finance, 47(4), 1425-1460. DOI: 10.1111/j.1540-6261.1992.tb04664.x

Received: 2018-07-13

Revisions requested: 2018-09-05

Revised: 2018-10-02

Accepted: 2018-10-30 


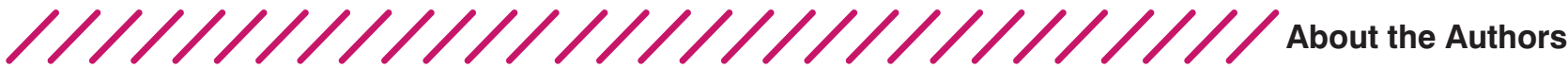

Ss. Cyril and Methodius University in Skopie, Faculty of Naumoski aleksandar@eccf.ukim.edu.mk

Aleksandar Naumoski, PhD., is an Associate Professor in Finance and a Head of the Department of Corporate Financial Management at the Faculty of Economics at the Ss.

Cyril and Methodius University in Skopje. At the undergraduate studies he teaches

Financial Management, Capital Investments and Risk management. Also, he teaches Corporate Financial Strategy, Corporate Risk Management and Financial Management at the master studies. He earned his PhD in Finance from the Ss. Cyril and Methodius

University in Skopje, Faculty of Economics. In 2009 he was a visiting scholar at the George Washington University, School of Business - Washington DC, USA. Before he

started his academic career, he worked for the National Bank of the Republic of Macedonia in the Banking Supervision and Banking Regulation departments. He works for the Center of Excellence in Finance, Ljubljana, Slovenia as a trainer in the PACT and

TIAPS Certification programs in Macedonia under the curriculum developed by the Chartered Institute of Public Finance and Accountancy (CIPFA) from London, UK. He provides lectures in Financial Management, Financial Accounting and Public Sector

Accounting and Financial Reporting. His scientific interest is focused on corporate finance and investments, particularly on the equity risk premium, risk management, financial engineering, investments and financial management.

PéterJuhász

Corvinus University of Budapest, Corvinus Business School, Budapest, Hungary. peter.juhasz@uni-corvinus.hu

Péter Juhász, PhD, CFA, is an Associate Professor at the Department of Finance of the Corvinus University of Budapest. He received his MSc in Economics and PhD in Business Administration from the same university, and his primary research fields include business valuation, financial modelling, corporate finance, enterprise risk management, and business performance analysis. He is CFA charter holder and has served as a board member and secretary of the CFA Society Hungary for almost a decade. In addition to his research and teaching activity, he also regularly acts as a consultant for SMEs and trainer of various finance related courses both in the CEE

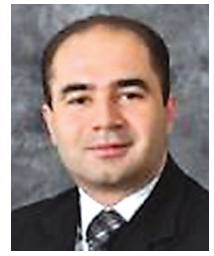
region and the Middle East. 